\title{
THE DAUGHTER YOU'VE ALWAYS WANTED
}

\section{Family matters.}

\section{BY STEVE PANTAZIS}

$\mathrm{T}$ The warmth of your interstitial fluids bathes me in a current of maternal bliss, and I revel in anticipation of becoming a newborn. The darkness comforts me, for I will never see, but I will feel and know the glorious sense of touch and taste, and the ravenous desire of want. I'll never hear on my own, but until the time that I leave the warmth of your body, you will be my ears, Mother. You are my host, and I am your child. Let our journey begin.

I suppose it all started when you stumbled upon my father. Was it love at first sight? I can't say, for all I could tell from your memories was your decadent scream as he sprang upon you. $\mathrm{Oh}$, he loved you, I know that, for he got you pregnant the very first try.

Sleep. You must not awaken, not yet.

I'm here to absorb your experiences, your bravery and mistakes, but most of all, your love. Teach me of your world, Mother, of you. I want to learn everything as you hibernate in your dreams.

I tighten just a little around your organs in excitement, a hug if you will, listening as you profess how you've always wanted a daughter. I wonder, as I gestate, how it might be if you had got your wish to produce a child with your own kind. Oh, I know you tried. You've cried so many times, considered yourself a failure, even lost your mate over it. This is your second chance. Forget your inadequacies, your hurts, your pain. Celebrate the life growing within you, the dream you've had since you were a little girl. You will have everything you want: I swear to it.

Murmurs penetrate your physical cavity from without. The murmurers are the crew of your starship. Their voices produce vibrations that tickle me, but you translate the words. They argue over how I will arrive. They concern themselves with your health, and one among them, whom they refer to as the ship's science officer, wonders how I will be preserved. The others don't welcome me, but my protector is curious, more intelligent and cunning than they are, and he won't allow any harm to come to me. I like him.

One of the murmurers drowns out the others. She's the ship's captain, the threat to our tranquillity. She wants to harm us,

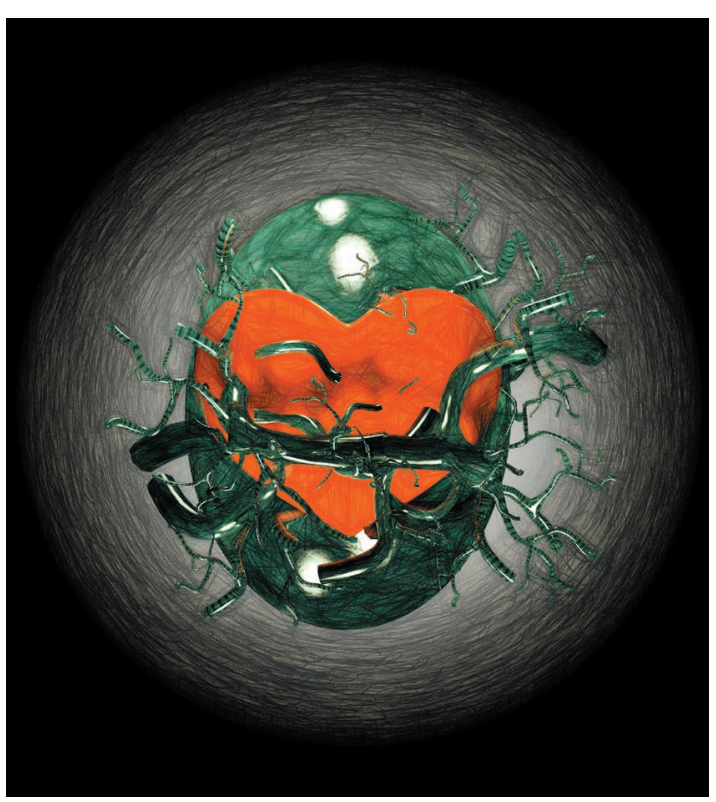

I nestle against your womb, that flattened space you originally chose for $\frac{0}{3}$ me. I know it saddens you I didn't take root there. You realize now, don't you, I belong next to your heart, because we beat as one. None of the murmurers understand, except the scientist. I will save him for last, I promise.

You convulse in your sleep. I've grown too large. The alarms from without bring the cluster of murmurers around us. They fight to save your life. You've lived long, I try to tell them, but they ignore me. Motherhood was a dream to you. Rejoice, Mother, for now your dream will come true.

The first contraction hits, and I push with all my might.

The murmurers scream, and it encourages me.

I push harder and puncture the fleshy barrier that has kept me safe since my father laid his first egg within you. A harm me, but especially you. You were a mechanic specialist, and she depended on you, although she despised everything about you: your reclusiveness, your unwillingness to conform, your readiness to report her when she ordered an unsanctioned landing on a world not on her manifest. She yelled at you, called you a pariah, forced the others against you. Now, she plots to flush you out of an airlock, and her co-conspirators agree. She's made you the enemy, Mother, all because she's a career woman and jealous you're with child. Don't let her win. You didn't before. You can't now.

Something sharp pokes into you, and tremors radiate micro-pulses of pain that jostle me within your folds. I respond as only I can, constricting around your heart and lungs. The science officer intervenes, and the captain relents, and her accomplices agree to leave you alone, for now. See, Mother, you're a fighter. When you were a child, that ugly creature Veronica bullied you, because she thought you were weak. She and her friends tried to humiliate you, but they miscalculated your potential. And just like you broke her nose, you $\rightarrow$ NATURE.COM the captain and her Follow Futures: $\quad$ spineless followers. y @NatureFutures Don't you dare give f go.nature.com/mtoodm up. I love you. spurt of blood erupts.

They scream again, and I pretend they're cheers.

A final push, and I burst through lung and lymph, tissue and bone. I'm free!

The world greets me in utter darkness, but I can see and hear through cranial senses in my exoskeleton. Oh, Mother, I've made a mess of you. You look so beautiful. I wish you could see yourself.

One of the murmurers goes to strike me, but my hero, the science officer, stops him.

I hiss my appreciation, then bolt for the open hatch. The murmurers don't follow, but I know they will come after me. I'm not afraid of them. I'm my mother's child, strong and independent. I'll be waiting for them in the cold dark of their ship.

I find a narrow space, hidden under the metal grating of a walkway. It's nice and cosy. I think I'll stay here for a while.

Thank you, Mother, for bringing me into this world. Thank you for sacrificing yourself so that I might live. Don't worry, I'll take care of your shipmates from here, especially the captain. I'll be the daughter you hoped I would be. I'll make you proud. His works have appeared in Writer's Digest, Galaxy's Edge and Writers of the Future, among other publications.
Steve Pantazis is a science-fiction author. 